\title{
The potential biodiesel production from Cerbera odollam oil (Bintaro) in Aceh
}

\author{
Khairil $^{1, *}$, Aulia Rizki $^{1}$, Iskandar ${ }^{1}$, Jalaluddin ${ }^{1}$, A.S. Silitonga ${ }^{1,2,3}$, H.H.Masjuki ${ }^{3}$, \\ T.M.I.Mahlia ${ }^{1,4}$ \\ ${ }^{1}$ Syiah Kuala University, Faculty of Engineering, Department of Mechanical Engineering, \\ 23111,Darussalam-Banda Aceh, Indonesia \\ ${ }^{2}$ Politeknik Negeri Medan, Department of Mechanical Engineering, 20155, Medan, Sumatera Utara, \\ Indonesia \\ ${ }^{3}$ University of Malaya, Faculty of Engineering Department of Mechanical Engineering, 50603 Kuala \\ Lumpur, Malaysia \\ ${ }^{4}$ Universiti Tenaga Nasional, Faculty of Engineering Department of Mechanical Engineering, 43000, \\ Kajang, Selangor, Malaysia.
}

\begin{abstract}
Biodiesel production from non-edible vegetable oils is an effective way to conquer the linked problems with edible oils such as food versus fuel and other environmental impacts. Cerbera odollam oil is one of these possible non-edible feed stocks for future biodiesel production. This study evaluated the potential biodiesel production from cerbera odollam. The seed was collected and extracted from Aceh, Indonesia. Moreover, biodiesel has been produced using degummed $\left(\mathrm{H}_{3} \mathrm{PO}_{4}\right)$ and two step acid catalyst $(\mathrm{HCl})$ and alkaline catalyst $(\mathrm{KOH})$. The results of properties of the cerbera odollam methyl esters show that such as viscosity was about 847.9 $\mathrm{mm}^{2} / \mathrm{s}$, density was $3.1578 \mathrm{~kg} / \mathrm{m}^{3}$, flash point was $214.0^{\circ} \mathrm{C}$, acid value was $0.4 \mathrm{mg} \mathrm{KOH} / \mathrm{g}$, oxidation stability was $6.35 \mathrm{~h}$, FAME content was $97.77 \%$ $\mathrm{w} / \mathrm{w}$ and heating value was $40.49 \mathrm{MJ} / \mathrm{kg}$. After analysing these properties, it has been found that there is a huge chance to produce biodiesel from this seed which complies with the limits of ASTM 6751 and EN 14214 specifications and therefore it can boost the future production of biodiesel from non-edible sources.
\end{abstract}

Keywords: Cerberaodollam, esterification, transesterification, biodiesel.

\section{Introduction}

The diminishing supply of fossil fuels reserves and the growing environmental concerns have made renewable energy an exceptionally attractive alternative energy source for the future [1,2]. Biodiesel is a promising alternative fuel for diesel fuel. It is defined as the mono-alkyl esters of long chain fatty acids derived from vegetable oils or animal fats and alcohol with or without a catalyst. It is renewable, biodegradable non-toxic, portable, readily available and eco-friendly fuel [3]. The Indonesian government has developed alternative fuel to tackle the energy crisis to solve the economic revival of society. Therefore, to the best of the author's knowledge, limited study on the possibility of cerbera odollam oil as a potential non-edible oil feed stock for biodiesel production has been reported in the literature.

\subsection{Objective of this study}

The purpose of this paper is to produce biodiesel from cerbera odollam oil using pretreatment degummed oil, homogeneous acid $\mathrm{HCl}$ catalyst and alkaline $\mathrm{KOH}$ catalyst

*) Corresponding author : khairil@msn.com 
followed by an investigation of some physical and chemical properties of the produced methyl ester (COME). The success of this study will promote more investigation of this feed stock for biodiesel production and eventually could yield promising and massive new raw material for biodiesel production on a large scale.

\subsection{Description of Cerbera Odollam}

Cerbera odollam belongs to mangrove family. It is native to the mangrove swamps of Asia, Australia, Madagascar, and the western islands of the Pacific Ocean. It is a medium to large tree with large, glossy, heart-shaped leaves that are conspicuously veined and longstemmed. The flowers are large and greenish; the sexes are separate. The fruit is oval and about the size of a large husked coconut, brown and rough-surfaced as shown in Fig.1. Cerbera odollam trees are abundant due to it is used as a coastal crop, greening and decorating the city park and requires no special maintenance [4]. Cerbera odollam seeds contain oil yield is about $43-64 \%$ [5].

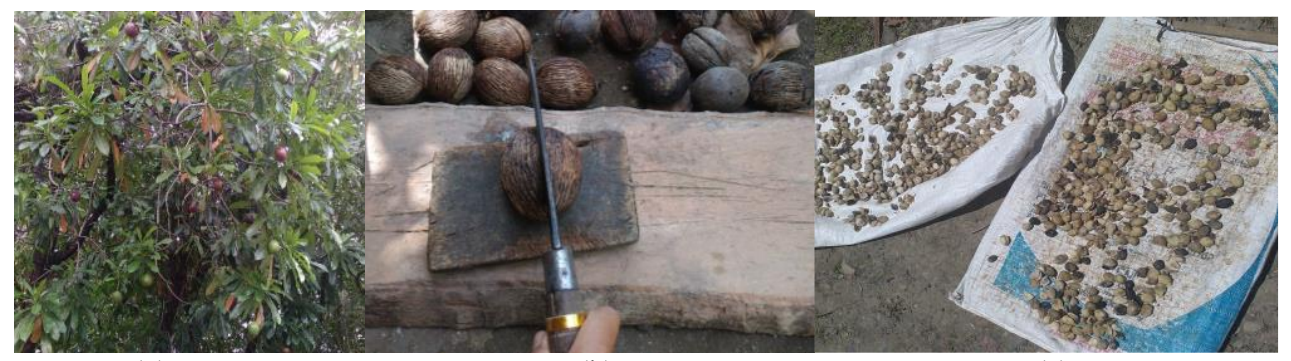

(a) (b)

(c)

Fig. 1 Cerbera odollam tree (a), fruit (b)and seeds (c)

\section{Material and Methods}

\subsection{Materials and Réagents}

The Cerberaodollam seeds was supplied from Banda Aceh, Indonesia through personal communication in order to obtain Crude Cerbera Odollam Oil (CCOO). Reagent chemical such as methanol, $\mathrm{H}_{3} \mathrm{PO}_{4}, \mathrm{HCl}, \mathrm{KOH}$ were used. Additionally, the qualitative filter paper (Filtres Fioroni, France) of $150 \mathrm{~mm}$ size was used to purify the crude oil from solidified matters.

\subsection{Methodology}

\subsubsection{Degumming process}

In this process, $0.7 \%$ (vol) of phosphoric acid $\left(\mathrm{H}_{3} \mathrm{PO}_{4} 20 \%\right.$ concentration) was added to crude cerbera odollam oil at a temperature of $70^{\circ} \mathrm{C}$ for 30 minutes in a glass beaker. This mixture was separated in separation funnelby density separation in which the phosphate compounds drop down at the bottom. The refined oil produced from this process was reported to be light yellow.

\subsubsection{Acid esterification}

*) Corresponding author : khairil@msn.com 
In this process, 100 gr of Crude Cerbera Odollam Oil (CCCO) was entered into a twonecked boiling flask equipped with a magnetic stirrer, reflux condenser and thermometer at room temperature. The sample of CCCO was mixed with 1:8 molar ratios of methanol and the mixture was stirring at a speed of $300 \mathrm{rpm}$. Then, hydrochloric acid $(\mathrm{HCl})$ was added to the sample drop by drop using a connected pipe to the flask. The amount of $\mathrm{HCl}$ catalyst added was $1 \%(\mathrm{v} / \mathrm{v})$. During the reaction, the mixture was stirring at constantly speed of $300 \mathrm{rpm}$ using a magnetic stirrer for 3 hours at $65^{\circ} \mathrm{C}$. The esterified oil was then removed from the reactor and entered into a separation funnel and left for 24 hours to remove the upper layer which includes extra and methanol from the lower layer of the first esterified CCCO.

\subsubsection{Alkaline transesterification}

In this process, cerbera odollam esterifed oil (COEO) was mixed with 29.76 gr of methanol while stirring at speed of $300 \mathrm{rpm}$. Then $2 \mathrm{gr}$ of $\mathrm{KOH}$ of alkaline catalyst using in this process was diluted which added to the oil and maintained at $60^{\circ} \mathrm{C}$ for 2 hours. The oil was then removed from the reactor and entered into a separation funnel left for 24 hours to remove the upper layer of cerbera odollam methyl ester (COME) oil from extra methanol and glycerol formed at the lower layer.

\subsubsection{Characterization of crude Cerbera odollam oil and methyl ester}

The crude cerbera odollam was found to be dark brown yellow. The physicochemical properties were tested according to the ASTM D6751 and EN 14214 standards. Several tests such as kinematic viscosity, density, flash point, acid value, oxidation stability, FAME content and heating value. Moreover, the fattyacid methyl ester (FAME) content in the biodiesel was measured by gas chromatography based on EN 14103 method which determined using the following equation [6]:

$$
F A M E=\left[\left(\sum A-A_{E I}\right) / A_{E I}\right] \times\left[\left(C_{E I} \times V_{E I}\right) / \mathrm{m}\right] \times 100 \%
$$

Where FAME represents the fattyacid methyl ester content (\%), $\sum A$ represents the total gas chromatography peak area of methyl ester, $A_{E I}$ represents the gas chromatography area of internal standard, methyl heptadecanoate, $C_{E I}$ represents the concentration of the standard solution $(\mathrm{mg} / \mathrm{ml}), V_{E I}$ represents the volume of the standard solution $(\mathrm{ml})$ and $m$ represents the amount of the biodiesel sample (mg). The methyl ester yield was determined using the following equation [7] :

$$
\text { Methyl ester yield }(\%)=\left[\left(F A M E \times W_{M E}\right) / W_{C O}\right] \times 100 \%
$$

Where FAME represents the fattyacidmethyl ester content (\%), $W_{M E}$ represents the weight of the cerbera odollam methyl ester $(\mathrm{g})$ and $W_{C O}$ represents the weight of the crude cerbera odollamoil (g). The equipment used to analyse physiochemical properties of crude cerbera odollam oil is listed in Table 1.

*) Corresponding author : khairil@msn.com 
Table 1. List of equipment used for biodiesel properties

\begin{tabular}{|l|l|l|l|}
\hline Property & \multicolumn{1}{|c|}{ Equipment } & \multicolumn{1}{|c|}{$\begin{array}{c}\text { Standard } \\
\text { method }\end{array}$} & \multicolumn{1}{|c|}{ Accuracy } \\
\hline $\begin{array}{l}\text { Kinematic } \\
\text { viscosity }\end{array}$ & $\begin{array}{l}\text { Stabinger viscometerTM SVM } \\
3000\end{array}$ & ASTM D7042 & $\pm 0.01 \mathrm{~mm}^{2} / \mathrm{s}$ \\
\hline Density & $\begin{array}{l}\text { DM40 LiquiPhysics } \\
\text { meter }\end{array}$ & ASTM D127 & $\pm 0.1 \mathrm{~kg} / \mathrm{m}^{3}$ \\
\hline Acid value & Automation titration rondo 20 & ASTM D664 & $\pm 0.001 \mathrm{mg} \mathrm{KOH} / \mathrm{g}$ \\
\hline Flash point & $\begin{array}{l}\text { NPM 440 Pensky-martens flash } \\
\text { point }\end{array}$ & ASTM D93 & $\pm 0.1^{\circ} \mathrm{C}$ \\
\hline Heating value & $\begin{array}{l}\text { 6100EF Semi auto bomb } \\
\text { calorimeter }\end{array}$ & ASTM D240 & $\pm 0.001 \mathrm{MJ} / \mathrm{kg}$ \\
\hline FAME content & QP2010 Ultra, Shimizu & EN 14103 & $\begin{array}{l} \pm 0.008 \% \text { or } 0.0008 \\
\mathrm{~min}\end{array}$ \\
\hline Oxidation stability & 873 Rancimat & EN 14112 & $\pm 0.01 \mathrm{~h}$ \\
\hline
\end{tabular}

\section{Results and discussion}

\subsection{Physico-chemical properties of Cerberaodollam methyl ester}

The physical and chemical properties of the cerbera odollam methyl ester (COME) produced were analyzed using ASTM specification: kinematic viscosity at $40^{\circ} \mathrm{C}$ (ASTM D445), density at $15^{\circ} \mathrm{C}$ (ASTM D1298), flash point (ASTM D93), acid value (ASTMD664), heating value (ASTM D240) etc. The physical and chemical properties of COME are listed in Table 2. The viscosity of the CPME is $4.56 \mathrm{~mm}^{2} / \mathrm{s}$, thus meeting the requirements of both the ASTM D6751 and EN-14214 biodiesel standards, which prescribe viscosity ranges that should be between $1.9-6.0$ and $3.5-5.0 \mathrm{~mm}^{2} / \mathrm{s}$, respectively. The density of methyl ester usually varies between 860 and $900 \mathrm{~kg} / \mathrm{m}^{3}$. The density of the COME is $878.10 \mathrm{~kg} / \mathrm{m}^{3}$. The acid value of COME was observed to be $0.47 \%$. These results are in agreement with the value specified in ASTM D664.The heating value of cerbera odollam methyl ester was found $39.46 \mathrm{MJ} / \mathrm{kg}$ respectively.

\subsection{Fatty acid methyl ester of COME}

The fatty acid methyl ester of the COME is shown in is shown in Fig.2 and a picture for the produced biodiesel is shown in Fig. 3. It can be seen that the COME biodiesel is mostly composed of oleic acid (19.33\%), linoleic acid (20.15\%), linolenic acid (9.82) and palmitic acid $(17.10 \%)$. The total unsaturated fatty acid content of the COME is found to be $54.08 \%$ which contributes to the improve deoxidation stability [8]. The composition of fatty acids in methyl ester may affect oxidation stability. This can be explained that the content of unsaturated fatty acids are sensitive to oxidative degradation, as well as unsaturated fatty compounds have higher flash points than saturated fatty compounds $[9,10]$.

*) Corresponding author : khairil@msn.com 
Table 2.Physicochemical properties of cerbera odollam methyl ester

\begin{tabular}{|l|l|c|c|}
\hline Property & COME & Limit ASTM D6751 & Limit EN 14214 \\
\hline Kinematic viscosity at $40^{\circ} \mathrm{C}\left(\mathrm{mm}^{2} / \mathrm{s}\right)$ & 847.9 & 880 & $860-900$ \\
\hline Density at $15^{\circ} \mathrm{C}\left(\mathrm{kg} / \mathrm{m}^{3}\right)$ & 3.1578 & $1.9-6.0$ & $3.5-5.0$ \\
\hline Acid value $(\mathrm{mg} \mathrm{KOH} / \mathrm{g})$ & 0.4 & Max. 0.5 & Max. 0.5 \\
\hline Heating value $(\mathrm{MJ} / \mathrm{kg})$ & 40.490 & 35 & - \\
\hline Flash point $\left({ }^{\circ} \mathrm{C}\right)$ & 214.0 & Min. 130 & Min. 101 \\
\hline Oxidation stability (h) & 6.35 & 3 & 6 \\
\hline FAME content $(\%)$ & 97.77 & - & 96.5 \\
\hline
\end{tabular}

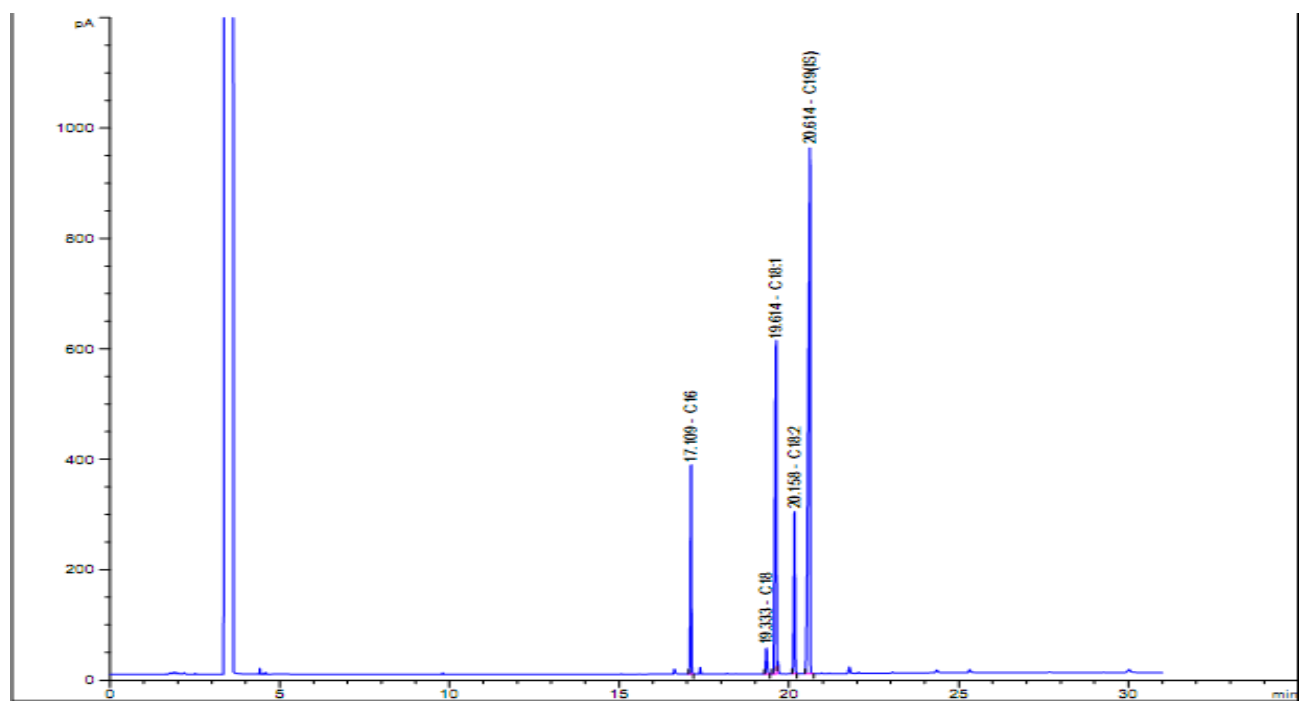

Fig. 2 Gas cromathography of cerbera odollam methyl ester

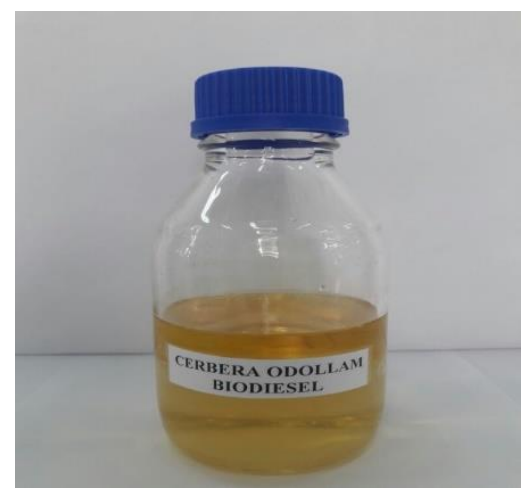

Fig. 3 Cerbera odollam biodiesel

*) Corresponding author : khairil@msn.com 


\section{Conclusion}

Cerbera odollam oil is one of non-edible feedstocks which can replace fossil diesel. The evaluation of biodiesel production using two step acid esterification and alkaline transesterification was performed in order to obtain high methyl ester yield. In this study, the FAME of cerbera odollam biodiesel attained $99.77 \% \mathrm{w} / \mathrm{w}$ and the measured properties were within the limits EN14214 and ASTM D 6751 standards. The results show that all of the reaction variables which clearly influenced the acid esterification and alkaline transesterification in a positive manner. From all of these encouraging out comes, and given further work testing on diesel engine performance, crude cerbera odollam oil could be recommended as a supplementary non-edible oil feedstock for biodiesel production.

The authors graciously acknowledge for the financial support provided from Syiah Kuala University Banda Aceh, Indonesia through the Penelitian Professor No.: 04/UN11.2/PP/PNBP/SP3/2017. The authors also graciously acknowledge for a part of the financial support provided by Politeknik Negeri Medan, Medan, Indonesia, under the Research and Community Service Unit (UPPM-2017) and also Universiti Tenaga Nasional (Grant No.: 20160101FRGS). Besides this, the authors would also like to thank Dr. Surya Dharma and Dr. Abdi Hanra Sebayang for their valuable help and support.

\section{References:}

1. J. Yan, Y. Yan, Encyclopedia of Sustainable Technologies, Elsevier, Oxford,1, (2017)

2. N. Damanik, H.C. Ong, W.T. Chong, A.S. Silitonga, Energ Sources Part. A, 1 (2017)

3. R.L. Patel, C.D. Sankhavara, Renew. Sust. Energ Rev,71 (2017).

4. U. Anisa Rahmi, 2011, Kajian proses produksi biodiesel dari minyak bintaro dengan transerterifikasi, Tugas Akhir, IPB Bogor.

5. Imahara H, Minami E, Hattori M, Murakami H, Matsui N. and Saka S, Current situation and properties of oil/fat resources for biodiesel production, The 2nd International Conference on SEE (2006) 1-5.

6 S. Dharma, H.H. Masjuki, H.C. Ong, A.H. Sebayang, A.S. Silitonga, F. Kusumo, T.M.I. Mahlia, Energ Convers. Manage, 115 (2016)

7. F. Kusumo, A. Silitonga, H.C. Ong, H. Masjuki, T. Mahlia, A comparative study of ultrasound and infrared transesterification of Sterculia foetida oil for biodiesel production, Energy Sources, Part A: Recovery, Utilization, and Environmental Effects, (2017) 1-8.

8. G. Martínez, N. Sánchez, J.M. Encinar, J.F. González, Fuel properties of biodiesel from vegetable oils and oil mixtures. Influence of methyl esters distribution, Biomass and Bioenergy, 63 (2014) 22-32.

9. G. Knothe, Fuel Proces, Technol, 86 (2005).

10. S. Schober, M. Mittelbach, Europ. J. Lipid Science Technol, 106 (2004)

*) Corresponding author : khairil@msn.com 